\title{
Complex, Critical and Caring: Young People's Diverse Religious, Spiritual and Non-Religious Worldviews in Australia and Canada
}

\author{
Anna Halafoff ${ }^{1, * \mathbb{D}}$, Heather Shipley ${ }^{2}$, Pamela D. Young ${ }^{3}$, Andrew Singleton ${ }^{4}{ }^{\circ}$, \\ Mary Lou Rasmussen ${ }^{5}$ (D) and Gary Bouma ${ }^{6}$ (D) \\ 1 School of Humanities and Social Sciences, Deakin University, Melbourne, VIC 3125, Australia \\ 2 Department of Classics and Religious Studies, University of Ottawa, Ottawa, ON K1N 6N5, Canada; \\ hshipley@uottawa.ca \\ 3 School of Religion, Queens's University, Kingston, ON K7L 3N6, Canada; youngpd@queensu.ca \\ 4 School of Humanities and Social Sciences, Deakin University, Geelong, VIC 3125, Australia; \\ andrew.singleton@deakin.edu.au \\ 5 School of Sociology, Australian National University, Canberra, ACT 0200, Australia; \\ MaryLou.Rasmussen@anu.edu.au \\ 6 School of Social Sciences, Monash University, Melbourne, VIC 3800, Australia; Gary.Bouma@monash.edu \\ * Correspondence: anna.halafoff@deakin.edu.au
}

Received: 12 February 2020; Accepted: 30 March 2020; Published: 3 April 2020

\begin{abstract}
Recent scholarly and media perspectives on religion and youth have often depicted young people as being apathetic when it comes to religion. The methods used in research on religion are also typically informed by outdated, fixed idea of religious identity that are no longer applicable, especially to young people. This paper confronts these issues by applying contemporary theories of religious diversity, including lived religion and religious complexity, to the findings of the Canadian Religion, Gender and Sexuality among Youth in Canada (RGSY) study, the Australian Interaction multifaith youth movement project, and the Worldviews of Australian Generation Z (AGZ) study. These three studies revealed that young people negotiate their worldview identities in complex, critical and caring ways that are far from ambivalent, and that are characterised by hybridity and questioning. We thereby recommend that policies and curricula pertaining to young people's and societies' wellbeing better reflect young people's actual lived experiences of diversity.
\end{abstract}

Keywords: religion; diversity; young people; spirituality; non-religion; complexity; hybridity

\section{Introduction}

Dominant thinking on religion and youth assumes that young people are largely apathetic about religion (Carlson 2012; Lucas 2008; Lunau 2009; Ron 2010), and contemporary research on religion often uses outdated, fixed frameworks of religious identity to determine its methods. As a result, people's and notably young people's, lived and fluid experiences of negotiating religious, spiritual and non-religious diversity are frequently inadequately described (Halafoff and Gobey 2018; McGuire 2008; Shipley 2018; Young 2018). Three co-authors of this paper, Anna Halafoff, Heather Shipley and Pamela D. Young first raised these concerns, which emerged from their respective and then yet-to-be-published 
research findings in Australia and Canada, at a workshop on 'Religion, Youth and Identity' held at the University of Ottawa as part of the Religion and Diversity Project in $2014 .^{1}$

This paper addresses these issues by discussing the findings of Halafoff's Interaction study, Young's and Shipley's Religion, Gender and Sexuality among Youth in Canada (RGSY) study, and Singleton's, Rasmussen's, Halafoff's and Bouma's Worldviews of Australian Generation Z (AGZ) study. The latter study was in part informed by the prior two studies' findings. All three research projects revealed three main themes, in contrast to dominant opinions on religion and youth: that young Australians and Canadians display a far from 'whatever'/ambivalent attitude toward religion, and that their worldviews are characterised by hybridity and questioning. We also argue in this paper that young Australians and Canadians negotiate their worldview identities in complex, critical and caring ways.

This aligns with contemporary theories of religious diversity, including Meredith McGuire's Lived Religion (2008), Nancy Ammerman's Everyday Religion (2007), Linda Woodhead's 'New Style Religion' (2012) and Inger Furseth's application of complexity theory (2018a, 2018b) to the study of religious diversity. These theories have arisen from research that was mainly focused on adults in the USA, UK, and the Nordic countries, which will be explored in more detail below. Moreover, as Steven Vertovec (2007) noted over a decade ago, public policy, understanding and research still does not adequately reflect the complex, lived superdiverse realities of peoples', and in this case, young people's lives. We thereby also recommend that young people's worldviews be considered more seriously among stakeholders responsible for policies, and also curricula pertaining to diversity and wellbeing, to better match these young people's actual lived experiences.

\section{Methods}

As stated above, this paper reports data from three studies of the worldviews and religious identities of Australian and Canadian Youth—the Interaction study, the Religion, Gender and Sexuality among Youth in Canada (RGSY) study, and The Worldviews of Australian Generation Z (AGZ) study. The InterAction study, conducted in 2013-2014, comprised 11 interviews with religious and non-religious young persons, aged between 20-31, who were all engaged in the Australian interfaith youth movement Interaction (Halafoff and Gobey 2018). The Religion, Gender and Sexuality among Youth in Canada (RGSY) study, conducted in 2012-2014, surveyed 486, 18-25-year-old participants from a wide variety of religious and nonreligious backgrounds (Young and Shipley 2020). The Worldviews of Australian Generation Z (AGZ) study, conducted in 2016-2018 focused on religion, sexuality and young people. The AGZ study comprised three stages: 11 focus groups with a total of 94 students in Years 9 and 10 (ages 15-16); a nationally representative random-digit-dial (RDD) telephone survey of 1200 people aged 13-18; and 30 in-depth, follow-up interviews with survey participants (Singleton et al. 2019). The findings of these studies are presented thematically below, as they relate to contemporary theories of religious diversity outlined in the next section.

\section{Risks and Religious Complexity}

The events of 11 September 2001 and the 2005 London bombings catapulted religion into the public mind and resulted in a securitisation of religion. Fears of homegrown terrorism resulted in young people being seen as at risk of radicalisation, and consequently as risks to broader society (Lentini et al. 2009; Mansouri and Halafoff 2014). Following these events, scholars in the US such as Ammerman (2007) and McGuire (2008) chose, by contrast, to highlight 'lived' and 'everyday' aspects of religion and spirituality. This research uncovered the fact that dominant frameworks and methods

1 These workshop papers were published in 2018 in Youth, Religion and Identity in a Globalizing Context, eds. Paul L. Gareau, Spencer Culham Bullivant and Peter Beyer. Leiden: Brill—see References for details. 
for understanding religion and spirituality in contemporary societies were inadequate and needed to better reflect people's actual experiences.

McGuire (2008) observed how complex and diverse the contemporary religious lives of adults in the USA are. Rather than subscribing to the beliefs, norms and practices of a single religious organisation, she instead found that an individual's religious experiences are 'ever-changing, multifaceted ... messy—even contradictory' (McGuire 2008, p. 4). People blend "traditional" religious practices with newer religious and/or spiritual expressions, and the boundaries between these are often blurry. She also found that 'people construct their religious worlds together', through shared experiences and meanings, so they are relational and social (McGuire 2008, p. 12). People can also be critical of religion, including their own religious leaders, and at the same time be inspired by their religious teachers and teachings to stand up against injustices. Consequently, McGuire called for scholars to examine 'everyday religion as lived' with a focus on embodied practices, experiences and expressions (McGuire 2008, p. 1).

Ammerman (2013) also problematised the binary where typically, religion is thought to be organised, communal, and declining, while spirituality is viewed as more individual, innovative and increasing in popularity. Instead she found, in her research based on adults in the US, that religion and spirituality actually shared many common characteristics, such as believing in God or a divine power, participating in shared practices, and following ethical frameworks. She also stressed that people could be spiritual and religious concurrently (Ammerman 2013).

When summarising the findings of her Religion and Society Programme in the UK, which involved studies of adults and young people, Woodhead (2012) similarly argued that while 'old style religion' centred on identification with one religious tradition and abiding by its rules, combined with regular attendance and participation in local religious practices, 'new style religion' is characterised by individual choice, fluidity, and hybridity. She also noted that the new style hasn't simply replaced the old, but that rather 'everything [is] going on at once', with both old- and new style religion existing alongside a rise of spirituality and the non-religious, and at times overlapping with one another.

More recently, Furseth (2018a, 2018b), in her research on the changing demographics and public role of religion in the five Nordic countries, relatedly argued that 'religious complexity' best describes contemporary religion, with 'seemingly contradictory trends,' of 'religious decline, growth, and change' happening concurrently (Furseth 2018a, p. 16). These include a decline in individual religiosity, a growth in religious diversity, an increasing interest in alternative spirituality and 'public visibility of religion', but also a continuity of religion's presence in the public sphere (Furseth 2018b, pp. 292-93).

It follows that contemporary expressions of worldviews-be they religious, spiritual and/or non-religious-in the USA, UK and in Nordic societies, can be categorised as complex, changeable and hybrid, and that these worldviews also often inform people's ethical positions and actions. While most of the above research has focused on adults, our data on young Australians and Canadians certainly also support these assertions and provide additional details about how young adults negotiate their intersecting and fluid worldviews.

Generations $\mathrm{Y}$ and $\mathrm{Z}$ have been raised in a time where religion has been more prominent in the media and public life following the events of 11 September 2001. Concurrently, there has been a dramatic rise in people declaring themselves to have 'no religion', particularly in Western societies such as Australia and Canada, and a robust critique of religion in the public sphere. A total of $29 \%$ of Canadians and 30\% of Australians describe themselves as religiously unaffiliated (Lipka 2019; ABS 2017). Our research has found that there is a growing trend among young people to identify as non-religious, or spiritual but not religious, at the same time as some of them remain religiously committed. Young people also live, study and work in increasingly superdiverse societies, in terms of not only religion and culture, but also gender and sexuality. As a result, they have been exposed through the media to public debates pertaining to various diversities and contestations between them, such as in marriage equality debates and through the \#Metoo movement. At the same time, both Australia and Canada provide very little education about religious, gender and sexuality diversity in state schools, 
and these are also 'hot' and controversial topics (Rasmussen 2006; Bouma and Halafoff 2017; Singleton et al. 2019; Young and Shipley 2020). All three studies-Interaction, RGSY and AGZ-have examined these issues to some degree.

We now turn to three main themes that emerged from the three studies' findings on young Australians and Canadians worldviews, namely, a lack of ambivalence/'whatever' attitudes, and growing hybridity, and questioning pertaining to religion among this cohort. We also examine how these young people negotiate their worldview identities in complex, critical and caring ways. These assertions are explored in more detail below.

\section{Whatever?}

Previous analyses of religion and youth in Australia have focused on how secularism, individualism and consumerism have led to a decline in religious affiliation, and a general lack of interest in, and ignorance about, religion among Australian youth. They have presented young people's engagement with religion and spirituality as being largely trend-based and somewhat shallow, and strongly influenced by social media and popular culture (Halafoff and Gobey 2018; Lucas 2008; Possamai 2009).

By contrast, Halafoff and Gobey (2018) in their Interaction study provide a signpost to the importance of religion in the lives of young people who are committed to interfaith activism, evident in their career and lifestyle choices. These young Australians, including Buddhist, Christian, Hindu, Muslim and Atheist participants, certainly did not hold a 'whatever' (Lucas 2008), ambivalent or indifferent view of, or approach toward, religion. Far from it, they took religion seriously, and were deeply engaged in religious thought and practices, and/or in critiquing religion from a young age. As this study only included 11 interviewees active in an interfaith movement, it's findings certainly weren't representative of all Australian youth, but were nonetheless interesting as they challenged previous assumptions regarding the religious indifference believed to characterise the entirety of Gen Y.

Shipley (2018, p. 191) also noted how young people's religious identities are often 'essentialised' and 'frequently represented' and 'misunderstood as apathy' (Carlson 2012; Lunau 2009; Ron 2010). The RGSY study instead found that young Canadians had 'articulate passionate, engaged and dynamic religious identities' (Shipley 2018, p. 192). Participants in the Canadian study were deeply concerned about justice, values and making the world a better place, whether or not they explicitly articulated these goals as religious. Participants also worked hard to negotiate their (non)religious lives in relation to their other cultural and social values (Young and Shipley 2020).

The AGZ findings clearly establish the dynamism that characterises young people's religious affiliations. The AGZ study used latent class analysis of the teens' worldviews to identify six statistically distinct types: $23 \%$ 'this-worldly'/non-religious, $15 \%$ indifferent, $18 \%$ spiritual but not religious, $8 \%$ religious and spiritual, $20 \%$ nominally religious and $17 \%$ religiously committed (Singleton et al. 2019). ${ }^{2}$ These are significant findings, as they document the complexity of worldviews held by AGZ teens. The AGZ study highlights the differences among those who are non-religious as being either 'this-worldly', 'indifferent', or 'spiritual but not religious'. At the same time, the substantial presence of the religious types, the 'religiously committed', 'nominally religious' and 'religious and spiritual', of young people further complicate the picture in this study.

As the vast majority of AGZ teens chose to identify as 'this-worldly', 'spiritual but not religious', 'religious and spiritual' and 'religiously committed', with only a minority of $15 \%$ who are religiously indifferent/'whatever' and $20 \%$ who are nominally religious. It follows that their non-religious, religious and/or spiritual worldviews are important to most AGZ teens. To illustrate, one AGZ interviewee was born into a Buddhist family but this wasn't particularly central to her until as a teenager she became involved in regular charity work, by volunteering to fundraise for natural disaster aid, conducted by

2 Percentages may not add up to 100 due to rounding. 
her local Buddhist temple. She described this as a 'life-changing' experience. She now attends the temple regularly and lights incense and prays each night at her family's home altar with her mother.

This section has highlighted how, while a significant proportion of young Australians and Canadians are religiously indifferent, they are a minority, and ambivalence certainly does not categorise the entire cohort. Instead, their religious, non-religious and spiritual identities are complex, similar to what Furseth (2018a, 2018b) has observed. They haven't replaced old style with new style religion, and aren't all turning away from religion either (Woodhead 2012). Religion, being this-worldly and/or spirituality, are all things they identify with, and that many of them care about and take seriously. This also, at times, inspires them to be caring toward others, as McGuire (2008) also noted. It is indeed, as Woodhead (2012) exclaimed, all going on simultaneously!

\section{Hybridity}

Another theme that emerged across the three studies was hybridity when it came to young Australian and Canadian's diverse worldviews. This hybridity and complexity, as scholars have previously noted (McGuire 2008; Halafoff and Gobey 2018; Shipley 2018), needs to be considered in terms of the methods used to ascertain people's worldviews. Asking people to simply tick one box on a census form or specify a religious or non-religious identification is no longer an adequate measure of what young people believe, or of what institutions they embrace or reject. This has implications for law, policy and curricula that focus on religion and belief, as a single, old-style category of practice and belonging. Asking questions linked to religiosity only tends to overstate the significance of dominant religions and to obfuscate young people's other worldviews, both religious and non-religious. The Interaction and RGSY studies revealed these limitations and hybridity as a significant trait among this cohort. The AGZ study's design, informed by the Interaction and RGSY's findings, set out not to simply offer limited, fixed categories for participants to choose from. It provided opportunities for AGZ teens to identify not only as non-religious, religious and/or spiritual, as described above, but as having more than one religious identification. It also presented a wide range of choices pertaining to sexual identity, allowing for more complex and hybrid identifications. ${ }^{3}$

The Interaction study found that hybridity was a central characteristic of young Australians' religious identities. This was largely as a result of processes of globalisation and their, and their parents' off and online mobility. This included conversion from Christianity to Tibetan Buddhism, and from Judaism to Eckankar ${ }^{4}$ among their parents, and interests in and identification with spirituality and religion, or spirituality and non-religious worldviews (Halafoff and Gobey 2018).

In the RGSY study, Shipley (2018, p. 193) also identified hybridity as a characteristic of this cohort, whose religious, non-religious and/or spiritual identities were 'varied and complex' (Shipley 2018, p. 19). In the final RGSY English survey, respondents identified as follows: Buddhism 1.9\%, Christianity $61 \%$, Hinduism $0.9 \%$, Islam $4.3 \%$, Judaism $3.3 \%$, Sikhism $0.2 \%$. as non-religious $20.3 \%$, spiritual but not religious $14.2 \%$ and other $9.2 \%$ (includes theist, agnostic, Wiccan, combination of religions, etc.). The RGSY study also revealed a substantial hybridity among the sample of Christian participants who also engaged with and practiced other traditions such as Wicca, Buddhism, and other spiritual practices (Shipley 2018, p. 194). Respondents described how they were exposed 'to multiple types of religiosities and practices at home, in school, in religious organisations, and online' (Shipley 2018, p. 197) and how they often engaged in a variety of diverse religious practices. Many participants were not content to claim one (non) religious identity. The often claimed several (Young and Shipley 2020).

The AGZ study set out to further investigate religious and/or non-religious hybridity, and by doing so it revealed two main types of hybridity among Australian teens. Firstly, it provided respondents

3 A detailed elucidation of the methods employed in the AGZ study is contained in Rasmussen, M., Graefenstein, S., Singleton, A., Halafoff, A., and Bouma, G. (forthcoming). 'Methodological Challenges of designing a Survey to capture young people's (non-binary) affiliations in relationship to religion, sexuality and gender,' International Journal of Social Research Methodology.

4 Eckankar is a new religious movement, founded in 1965. 
with the capacity to select more than one religious identity in the survey. Eight per cent of participants who identified as religious identified with more than one religious tradition (approximately $3 \%$ of all teens), and this was largely as a result of having parents from different religious traditions. Participants were asked to identify with only one religion or non-religion first, so that the AGZ data could be compared with previous studies that only allowed for one religious identification. Once they had done so the AGZ participants were then given the opportunity to also identify with other traditions.

Of the Christians, 17 teens identified with more than one Christian tradition, seven identified with Christianity and Buddhism, six identified with Christianity and an other religion, two identified with Christianity and Islam. Of the Buddhists, two identified as Christian also, and one identified as another religion as well. Of the Hindus, one identified as Christian also, and one identified as Sikh as well. Of the Muslims, one identified as Christian also. Of the Jews, one identified as Christian as well. While this is a small sample of the 1200 participants in the AGZ survey, it is nonetheless still a significant finding.

In the AGZ focus groups, students noted both the benefits and challenges of growing up in families with two religious traditions. One student favourably described their Jewish-Christian family and how they celebrated both customs: ' ... some people are, like half Jewish, half Christian or, like, have a bit of Christian. So, like ... I celebrate Christmas and stuff. So I feel like-there-like a lot of us are Jewish but then also have other cultures that they celebrate with their families.' Another student, by contrast, noted the tensions of being raised in a dual religious family and negotiating their hybrid religious identity. They said, '[m]um's side is Catholic and my Dad's side is Buddhist ... And it's kind of contradicting.'

The second, and more prevalent, form of hybridity in the AGZ sample was that of being spiritual and religious, or spiritual and [but] not religious. While 35\% of respondents said they were neither religious or spiritual, and $12 \%$ were 'religious but not spiritual', $22 \%$ said they were 'spiritual but not religious', and $16 \%$ were 'religious and spiritual'. Fourteen percent could not choose from those categories. In terms of the AGZ teens' spiritual alternative practices and beliefs, $20 \%$ believed in astrology, 30\% in reincarnation, 50\% in karma and $22 \%$ had practised yoga and $30 \%$ had practised meditation (outside of school) (Singleton et al. 2019).

For example, when pondering her relationship to spirituality and religion, one AGZ interviewee said, 'I would say I am, um, spiritual I guess'. She explained, to her, that being spiritual meant that 'you believe there is like a higher order out there somewhere.' She described how she is 'a firm believer in like karma and like if you do good things in the world you will receive good things' which she acknowledged came 'definitely from the Buddhist side' of her family, given that her parents were Buddhist and she had been raised 'sort of Buddhist'. However, she also said she was 'agnostic' about rebirth/reincarnation. Despite not identifying as, or necessarily being, religious, this interviewee was aware of the influence that elements of both Buddhism, from her parents, and Catholicism, and Catholic values from her Catholic schooling, had had in shaping her spiritual identity and beliefs.

Another AGZ interviewee described how she was vegan, concerned about animal rights and had some interest in crystals and meditation. Her main spiritual practice was Tarot cards and she explained how, 'tarot cards are something if I don't know what to do in a certain situation, I would use them and then try and like get some clarity. And I think that's probably what people do with religion too.' This interviewee was introduced to various spiritual and religious practices and beliefs by her father, who had been religiously experimental throughout his life (as many parents of the AGZ interviewees were). As she describes it: 'he was really into Christianity at one point and then he was really into Buddhism and stuff like that.' While she didn't describe herself as religious, she spoke about her attraction to all religions. In addition to her father's influence, her understanding of her own religious and spiritual life was significantly shaped by her Studies of Religion course in her final years of schooling. It was through the course that she ultimately came to think of herself as 'new-age kind of religious'.

These findings reveal that similarly to what McGuire (2008), Ammerman (2013) and Woodhead (2012) have argued, hybridity and complexity are factors in these young Australian and Canadian's 
religious, non-religious and/or spiritual identities, and that these findings should inform research methods, and questions, as well as policy and curricula related to religion, spirituality and young people.

\section{Questioning}

Questioning of religion among young people, pertaining to their identity but also, more broadly, religion in society, was another major finding of the Interaction study. While most participants' religious identities were more influenced by their parents than other factors, such as their peers, school or popular culture, many of them were adhering to their parent's religious traditions and questioning them concurrently. They certainly frequented websites and blogs, but not in a superficial or consumerist manner. Rather, they searched the internet with intention, to answer their genuine questions about religion and life's meaning. Their attitude to religion was critical and deeply considered. They were broadly accepting of religious diversity, curious about religions, and wanted to know more about them. Once again, they certainly cared about these issues (Halafoff and Gobey 2018). For example, one of the Interaction Christian interviewees stated:

I'm struggling with that a little bit at the moment and I think I would more call myself spiritual rather than ... it's sort of tough. I think it's an age thing ... I'm not really sure whether Christianity as such and Anglicanism ... is really where I'm at entirely so ...

Another Interaction respondent explained how he became an atheist, both through questioning religious belief and through researching religion on the internet:

It was through, for me an experience when I was 17 years old. I went on student exchange and I was situated in ... the Bible Belt in the United States. And so staying in America and living with a family that was very religious and all of my high school friends were very Evangelical Christian believers. That sort of forced me to make up mind about what I believed in and you know the questions were 'is there a God, is the Bible the word of God, was Jesus the son of God, is evolution true,' all of these questions all of a sudden were very important to me ... arriving at my own conclusion, I guess that science was the best tool to figure out the reality of the world.... I did a lot of reading online and I read a lot of books ... There were a lot of Atheist sort of blogs. And ... it was just something I was really passionate about ...

Shipley (2018, p. 193) also identified hybridity and 'questioning' as characteristics of the RGSY cohort. For example, one 24-year-old spiritual but not religious Canadian respondent, who had been raised Catholic, stated:

Right now, I'd say I'm at a confused stage, to say the least. I'm-I'm very interested in different aspects of different religions... I've also been in contact with quite a lot of Indigenous traditions ... and that has also been quite influencing [sic] ... I haven't, you know, given up believing altogether, but I'm also very confused and can't really identify where I stand.

Shipley (2018, p. 197) has highlighted that questioning of and complicated attitudes about religion often arose in young people as a result of conflicting views that some religions had pertaining to gender identity and sexuality equality. For example, one of the RGSY respondent's religious identity has been 'complicated ... by living in a common-law relationship with a transgender (female to male) partner'. In the respondent's conservative Catholic community, being transgender is unacceptable, and so this created 'a barrier in her personal self-identification as religious' and made her question religion more generally.

Another respondent specified her religious identity as 'questioning', given she was 'working through her personal disagreements with Catholic teachings (such as sex outside marriage, treatment of the lgbtqi community, and women's ordination)'. At the same time, she said that 'she feels strongly that she wants to raise her children within the Catholic tradition and get married in a Catholic Church ... wanting similar experiences and the community that it has offered to her' (Shipley 2018, pp. 197-98). Another respondent was raised in a Catholic household, but didn't experience a 'personal connection' with the Catholic teachings she received at home and in church. She questioned her religious identity and converted to Islam. At the time of her interview, she was engaging in both personal and online 
Islamic practices, as she could no longer attend her local mosque given what she described as its 'sexist, racist and homophobic' attitudes. She hoped to find a more progressive and inclusive mosque in future (Shipley 2018, p. 198).

It is important to note that participants in all three of these studies, while critically aware of religion's capacity to impinge at times upon the rights of others, were not entirely negative about religion. In the RGSY study, they also highlighted positive aspects of religion, such as its capacity to provide community and good values, such as respect for others, as things they valued (Shipley 2018, p. 200; Young and Shipley 2020).

This type of questioning regarding religion during teen years was also evident in the AGZ study. For example, one of the AGZ study interviewees, who has a parent who is a committed member of the Church of Latter-day Saints, described how, when she was a teenager, she went through an important time of personal questioning, to be sure that her religion was right for her and that she wasn't simply following convention. She explained how:

I was really young, like, from a baby on I've been part of that religion and then there was a point in time where I was like, when you're a teenager and you're thinking, there are so many options for me, what's going on, is this real, is this right, is this true, and it—it really did hit me and I was like, what am I doing? ... I didn't want to just go into life and be like yeah, this is the religion that I'm in and just like a follower. It was more like I wanted to make my choice and to see for myself if it was making me happy, and me 'me'.

Alongside this questioning, and similarly to the RGSY study, the vast majority of AGZ teens have a positive view of religious diversity and religious freedom. However, these positive views were often moderated when participants perceived conflicts between religious practice and the rights of others. While $93 \%$ of participants agree with the statement: 'Having people of many different faiths makes Australia a better place to live', AGZ teens' opinions were far more divided on issues where religion may have the capacity to impinge on their rights or to offend people. Half of Australia's teens $(50 \%)$ thought that people with very strong religious beliefs are often too intolerant of others and $45 \%$ thought that religion causes more problems than it solves (Singleton et al. 2019). These results display a critical awareness and strong questioning of religions' place in society, particularly in negotiation with other freedoms and rights. Students in one of the AGZ focus groups stated a variety of orientations toward questioning:

P1: ... I think a big thing about it is ... how we view religion can be in a sense altered by ... to an extent some people believe that [their] religion has to be the right one...

P2: I've only really disagreed with people about things, such as like I guess you could kind of call it political view or something or people who are like homophobic or something ...

P3: Well, I only have an issue with it if-I don't generally care what-what a person believes, as long as they don't try and implement the way they think on the way I think.

P2: Yeah, or-or as long as they are not, um, making specific reference or offending people with like their views.

In this exchange, we see participants concerned about religious people asserting that their faith is the "right one". Political views and homophobia are deemed ripe for contestation, especially if they are seen as offensive or imposing on individual beliefs. One of the spiritual but not religious AGZ interviewees echoed these sentiments when he described how his circle of friends had a 'variety of beliefs and religions', and that they 'all got along fine'. He added, 'the main thing was, I don't mind whatever you identify as, as long as you don't try and force your beliefs upon me.' Another nominally Hindu AGZ interviewee explained how:

I've noticed that it-it does kind of affect more when people push religion and their values. Like, I'm happy to know about it and respect theirs, but ... it kind of bothered me ... I think as long as 
people respect everyone's, um, kind of boundaries and their own beliefs, it's—it's justified to, um, be religious I guess.

In the excerpts above, AGZ participants repeatedly questioned beliefs that impacted upon the views and rights of others, but this discomfort with infringement is somewhat qualified ('kind of', 'I only have an issue if'). One senses that participants are inclined to live and let live, except when people are perceived to cross boundaries by imposing their beliefs on others, or if they're being explicitly intolerant. Potentially, this tendency towards qualification was a function of the methodology utilised in the study. Speaking with young people in focus groups meant they had to enunciate different types of worldviews in front of peers, a vulnerable move at any age. Qualification may provide focus group participants with an opportunity to voice opinions without appearing too strident themselves.

Similarly to the RGSY study findings, clashes between religious freedom and sexuality rights appeared to be a highly charged issue for participants. The AGZ survey was, coincidentally, conducted at the same time as Australia's non-compulsory postal vote on same sex marriage. AGZ teens, who were excluded from voting on the question of marriage equality, were highly supportive of sexuality diversity. Eighty-two percent of teens supported marriage equality, compared to the $62 \%$ of adults who voted for it in the Marriage Equality survey (Singleton et al. 2019).

Some students who participated in the AGZ focus groups were highly aware of internal tensions between progressive and conservative movements within religions. Moreover, in the post-survey interviews, when asked about religious exemptions to hire/fire staff in religious organisations, including schools, most AGZ teens were surprised that these exemptions even existed and were strongly opposed to them, especially when lesbian, gay, bisexual, trans and queer (LGBTQ) staff or students could be discriminated against on the basis of their gender or sexuality. This once again displays a strong critique of religion and a deep level of care about how LGBTQ people can be impacted by discrimination related to religious freedom.

In the surveys and interviews a direct relationship between religiosity and LGBTQ rights was also noted. Strongly held religious beliefs, among the 'religiously committed', were the most powerful indicator that a participant would be against LGBTQ rights and freedoms. This also portrays a level of critique of progressive pro-LGBTQ views and a strong sense of investment in these issues, although it also arguably depicts a lack of empathy regarding the negative impacts of prejudice against LGBTQ individuals and communities.

One religious and spiritual AGZ interviewee queried 'so they can still do that?', with regard to religious exemptions against LGBTIQ pupils and teachers. One religiously committed Buddhist said it was 'ridiculous' and a this-worldly non-religious teen simply incredulously said 'wow'. A this-worldly AGZ teen said: 'I just don't agree with that at all ... Just I think having to fire someone because-or like exclude a certain student or teacher from just being themselves, I think is just outrageous.' Finally, another AGZ this-worldly interviewee explained the hypocrisy of the conservative religious position in the religious freedom debate, which fights for the right to discriminate against others in the name of freedom, but only for their religious group at the expense of the rights of others:

I'm not particularly aligned with the concept of religious freedom. I figure if they're the set of rules, it doesn't really matter what you practice, you have to follow those rules. Like, also if, there's a lot of white Australians trying to fight the people wearing burqas, to take them off .... And they're quite opposed to having LGBT classes in the school, which is kind of along the same lines, when you think about it. So, religious freedom, but only for us.

Young Australian's and Canadians are often questioning their own religious, spiritual and/or non-religious identities, and these are fluid, and changing over time, similar to characteristics McGuire (2008) and Woodhead (2012) have observed regarding contemporary religious identity and participation. In addition, young Australian's and Canadians were most likely to question religious freedom when it impacts on others' rights, particularly rights pertaining to sexual and gender diversity and equality. This demonstrates their capacity for critical reflexivity and a sense of care pertaining to these issues, and particularly for LGBTQ persons, who may be subject to negative judgements and discrimination and 
impacted by state-sanctioned religious exemptions. Strongly religious young people, with anti-LGBTQ views, also provide evidence of questioning the dominant social norms of their peers, who largely favor LGBTQ equality. In all of the above cases, these are indubitably issues that young people take seriously.

\section{Conclusions}

This paper has explored how all three research projects, the Interaction, RGSY and the AGZ studies, revealed three main themes that young Australians and Canadians have a far from 'whatever'/ambivalent attitude toward religion, and that their worldviews are characterised by hybridity and questioning. We also revealed that young Australians and Canadians negotiate their worldview identities in complex, critical and caring ways.

Halafoff and Gobey (2018) found that the Interaction participants questioning did affirm narratives of individualism, as they were 'reflexively constructing, reevaluating, and reconstructing their own religious, spiritual and non-religious identities'. Concurrently, they noted that these young people's choices weren't simply made individually, as they were highly influenced by socialising agents such as their parents, peers, schools, and media. They thereby concluded that these young Australians religious, spiritual and/or non-religious identities were 'fluid, changing, and in many cases contain[ed] significant reflexive pauses' and that 'hybridity, mobility, commitment, questioning, and interconnectivity' characterised these young people's religious identity formation and interfaith youth engagement.

Shipley (2018, p. 200) also emphasised that the 'RGSY respondents are carefully negotiating these multiple aspects and possibilities' of being religious, spiritual, non-religious and/or questioning'. She added:

Being self-identified as questioning, spiritual but not religious (SBNR), or religious does not define in strict terms their identities or place them in neat boxes ... And the limited language could be a factor in widespread assumptions regarding youth's disinterest or apathy toward religion, beliefs and spirituality ... The language of religiosity is evolving and ... youth studies regarding religious identity lay bare the linguistic restrictions.

Shipley (2018, p. 205) also concluded that 'the evolving nature of belief, faith, identity and practice' of the RGSY religious and non-religious respondents, is 'thoughtful and considered', and influences the 'clear choices' they are making in 'their notions about social justice, kindness, compassion, and honesty'. Issues of sexuality equality, in particular, have had a profound impact on how they engage or chose not to engage with conservative religions.

The AGZ study's six worldview types provide further empirically robust evidence of religious complexity in Australian society, and evidence that only a minority, 15\%, of AGZ teens are indifferent regarding religion and spirituality, and only $20 \%$ are nominally religious. This-worldly AGZ teens have strong opinions about religion and chose not to be identified as religious-this is a considered position. Similarly, spiritual but not religious teens have decided not to identify as religious, but rather as spiritual, and are engaged in a variety of spiritual practices and hold spiritual worldviews. Religion certainly plays an important role in the religiously committed teens' lives. Moreover, the AGZ focus group and interviewee data are rich with examples of religious hybridity and critical reflexivity when it comes to identity and debates on religious freedom, and the impact this may have on the rights of others and especially of LGBTQ persons. Whether they respected sexual diversity or not, AGZ teens really cared about these issues and, for the most part, thought that religious rights should not triumph over the rights of others.

The findings of these three studies on young Australians' and Canadians' worldviews, and particularly the three themes of a lack of ambivalence/'whatever' attitudes, hybridity, and questioning, as well as the three complex, critical and caring ways in which they negotiate their worldview and identities, align with McGuire (2008), Ammerman (2013), Woodhead (2012) and Furseth's (2018a, 2018b) studies. They also highlight the need for a greater awareness of the complexity of young people's lived realities when it comes to religion, spirituality and non-religion. This is of great significance when it comes to education, health and wellbeing policies, curricula and practices for young people, which are 
still often informed by outdated and limited understandings or biases when it comes to religion. Our findings may also inform other scholar's research on religion and young people in diverse contexts, and research on religion in contemporary society more broadly.

Finally, young Australian and Canadian's exposure to public debates involving religious freedom and other rights - notably sexuality rights - and their cognizance and criticisms of religions' capacity to impinge upon the rights of others, is having a profound effect on shaping young people's identities and worldviews. This may indeed be a significant factor related to future decline in religious affiliation. The opinions of young people must be considered in these debates, as the majority of them will not abide with religious rights being able to triumph over and above the rights of others, and certainly not when it comes to sexuality rights. Consequently, we argue that current policy and legal debates on LGBTQ rights, religious freedom, and religious exemptions, heed the complex, critical and caring voices of young people.

Author Contributions: Conceptualization, A.H., H.S., P.D.Y., A.S., M.L.R., G.B.; formal analysis, A.H., H.S., P.D.Y., A.S., M.L.R., G.B.; writing—original draft, A.H., H.S., P.D.Y., A.S., M.L.R., G.B.; writing—review and editing, A.H., H.S., P.D.Y., A.S., M.L.R., G.B.; All authors have read and agreed to the published version of the manuscript.

Funding: The Interaction study was supported by Deakin University's Central Research Grants Scheme; The RGSY research was supported by the Religion and Diversity Project (Social Sciences and Humanities Research Council of Canada Major Collaborative Research Initiative, led by Lori G. Beaman); The AGZ research was supported by the Australian Research Council, ARC Discovery Project: DP160102367.

Conflicts of Interest: The authors declare no conflict of interest.

\section{References}

ABS. 2017. 1266.0-Australian Standard Classification of Religious Groups. Canberra: Australian Bureau of Statistics. Ammerman, Nancy T., ed. 2007. Everyday Religion: Observing Modern Religious Lives. Oxford: Oxford University Press.

Ammerman, Nancy T. 2013. Spiritual but Not Religious? Beyond Binary Choices in the Study of Religion. Journal for the Scientific Study of Religion 52: 258-78. [CrossRef]

Bouma, Gary D., and Anna Halafoff. 2017. Australia's Changing Religious Profile-Rising Nones and Pentecostals, Declining British Protestants in Superdiversity: Views from the 2016 Census. Journal for the Academic Study of Religion 30: 129-43. [CrossRef]

Carlson, Kathryn Blaze. 2012. Organized Religion on the Decline: Growing Number of Canadians 'Spiritual But Not Religious'. National Post, December 21.

Furseth, Inger. 2018a. Introduction. In Religious Complexity in the Public Sphere: Comparing Nordic Countries. Edited by Inger Furseth. Cham: Palgrave, pp. 1-29.

Furseth, Inger. 2018b. Secularization, Deprivatization, or Religious Complexity. In Religious Complexity in the Public Sphere: Comparing Nordic Countries. Edited by Inger Furseth. Cham: Palgrave, pp. 291-312.

Halafoff, Anna, and Laura Gobey. 2018. 'Whatever': Religion, Youth, and Identity in 21st Century Australia. In Youth, Religion and Identity in a Globalising Context. Edited by Paul L. Gareau, Spencer Culham Bullivant and Peter Beyer. Brill: Leiden, pp. 255-78.

Lentini, Pete, Anna Halafoff, and Ela Ogru. 2009. Perceptions of Multiculturalism and Security in Victoria: Report to the Department of Premier and Cabinet, State Government of Victoria. Melbourne: Monash University.

Lipka, Michael. 2019. 5 Facts about Religion in Canada. FACTTANK, Pew Research Centre. July 1. Available online: https://www.pewresearch.org/fact-tank/2019/07/01/5-facts-about-religion-in-canada/ (accessed on 15 March 2020).

Lucas, Ben C. 2008. (Director) 2008. Y God. Available online: https://www.imdb.com/title/tt1730575/ (accessed on 20 March 2020).

Lunau, Kate. 2009. Youth Survey: Teens lose faith in droves, Islam and atheism are on the rise while Christianity fades. Maclean's, April 7.

Mansouri, Fethi, and Anna Halafoff. 2014. Introduction: migrant youth, intercultural relations and the challenges of social inclusion. Journal of Social Inclusion 2: 1-4. [CrossRef]

McGuire, Meredith. 2008. Lived Religion: Faith and Practice in Everyday Life. New York: Oxford University Press. 
Possamai, Adam. 2009. Sociology of Religion for Generations X and Y. London: Equinox.

Rasmussen, Mary Lou. 2006. Becoming Subjects: Sexualities and Secondary Schooling. New York: Routledge.

Ron, James. 2010. “Canada Adrift in Religious World. The Star, July 29.

Shipley, Heather. 2018. Apathy or Misunderstanding? Youth's Reflections on their Religious Identity in Canada. In Youth, Religion and Identity in a Globalising Context. Edited by Paul L. Gareau, Spencer Culham Bullivant and Peter Beyer. Leiden: Brill, pp. 191-211.

Singleton, Andrew, Mary Lou Rasmussen, Anna Halafoff, and Gary D. Bouma. 2019. Australia's Generation Z Study: Australia's Teenagers Negotiating Religion, Sexuality and Diversity. Project Report. Melbourne: Deakin University.

Vertovec, Steven. 2007. Superdiversity and its Implications. Ethnic and Racial Studies 30: 1024-54. [CrossRef]

Woodhead, Linda. 2012. New Forms of Public Religion: Findings and Reflections from the AHRC/ESRC Religion and Society Programme. Paper presented at the New Forms of Public Religion Conference, St. John's College, Cambridge, UK, September 5-7.

Young, Pamela D. 2018. Influences of Religion on the Sexual Attitudes and Practices of Canadian Youth: The Case of Premarital Sex. In Youth, Religion and Identity in a Globalizing Context. Edited by Paul L. Gareau, Spencer Culham Bullivant and Peter Beyer. Leiden: Brill, pp. 66-77.

Young, Pamela D., and Heather Shipley. 2020. Identities under Construction: Religion, Gender and Sexuality among Youth in Canada. Montreal: McGill Queen's University Press.

(C) 2020 by the authors. Licensee MDPI, Basel, Switzerland. This article is an open access article distributed under the terms and conditions of the Creative Commons Attribution (CC BY) license (http://creativecommons.org/licenses/by/4.0/). 